We thank Dr J Koch-Weser of Hoffmann-La Roche, Basle, Switzerland, for discussions in the planning of the study.

1 Wysenbeek AJ, Mor F, Lurie Y, Weinberger A. Imipramine for the treatment of fibrositis: a therapeutic trial. Ann Rheum Dis 1985;44:752-3.

2 Steinberg AD. On morning stiffness. I R heumatol 1978:5:3-6.

3 Helliwell $P$. The measurement of stiffness and strength in the rheumatic hand. Oxford: University of Oxford, 1987. 282 pp. (Thesis.)

(Accepted 11 September 1987)

Rheumatism Research Unit, University Department of Medicine, Leeds General Infirmary, Leeds

H A BIRD, MD, FRCP, senior lecturer in rheumatology

V WRIGHT, MD, FRCP, professor of rheumatology

Clinical Pharmacology Unit, Royal Bath Hospital, Harrogate, North Yorkshire

P LE GALLEZ, SRN, clinical metrologist

R BOJAR, BSC, research technician

J S DIXON, BSC, PHD, lecturer

Correspondence to: Dr Bird.

\section{Major abdominal operations on patients aged 80 and over: an audit}

Concern that the rates of death and complications after major abdominal operations in this hospital in a popular retirement area were inflated by the number of patients aged over 80 led us to conduct an audit of patients having such operations. (occurring within 24 hours), and 177 urgent (on patients admitted as emergencies and operated on after investigation). Altogether 194 operations $(43 \%)$ were for cancer. In the group of patients under 80,5301 similar operations were performed on 4992 patients (table).

Deaths-Among the patients aged 80 and over 89 (22\%) died, representing $20 \%$ of the operations. Twelve deaths were due to sepsis, 18 to pneumonia, and the rest to cardiovascular complications or cancer. Forty one patients $(29 \%)$ died after the 141 emergency operations, 26 (15\%) after the 177 urgent operations, and $22(17 \%)$ after the 128 elective operations. Mortality did not differ between men $(21 \%)$ and women $(21 \%)$, although that in men was lowered by the inclusion of 88 cases of retropubic prostatectomy with four deaths $(5 \%)$. Exclusion of these cases increased the mortality in men to $29 \%$, although this was not significantly higher than that in women $\left(\chi^{2}=1.84, p=0.18\right)$. The rate of necropsy was low $(44 \%)$. Of the patients under the age of $80,281(6 \%)$ died, representing $5 \%$ of operations.

Complications-Of the 446 operations in patients aged 80 and over, $306(69 \%)$ were followed by an uncomplicated recovery and 51 (11\%) by major complications, of which 34 were due to infection and 17 to other causes. In the patients aged under $80,4723(89 \%)$ of the 5301 operations were followed by recovery without complications.

\section{Comment}

The rates of death and complications after major abdominal operations on the elderly in this series are similar to those reported by Blake and Lynn in 1976. ${ }^{1}$ The mortality in their series of 375 patients was $32 \%$ with 228 major complications, although whether this meant 228 operations or that some patients had more than one complication is not clear. The risks of operating on the very old may be viewed in two ways. One view is that because of the frailty of such patients a major operation may be lethal, and the other is that they must be exceptionally tough to have lived past the age of 80 and are "biologically élite."2 The morbidity and mortality in reported series depend to some extent on the proportion of patients who were denied operation; this figure, however, is seldom reported.

We conclude that major operations in patients over the age of 80 are associated with increased risks of morbidity and mortality and that these risks are further increased in patients admitted as emergencies.

Deaths and complications in patients undergoing operation according to age

\begin{tabular}{|c|c|c|c|c|c|c|c|}
\hline Diagnosis & $\begin{array}{c}\text { No of } \\
\text { operations }\end{array}$ & $\begin{array}{c}\text { No }(\%) \text { of } \\
\text { deaths }\end{array}$ & $\begin{array}{l}95 \% \text { Confidence } \\
\text { interval for } \\
\text { proportions }\end{array}$ & Significance & $\begin{array}{c}\text { No }(\%) \text { of } \\
\text { major } \\
\text { complications }\end{array}$ & $\begin{array}{l}95 \% \text { Confidence } \\
\text { interval for } \\
\text { proportions }\end{array}$ & Significance \\
\hline $\begin{array}{l}\text { Upper gastrointestinal: } \\
\geqslant 80 \text { Years } \\
<80 \text { Years }\end{array}$ & $\begin{array}{r}115 \\
1661\end{array}$ & $\begin{array}{l}31(27) \\
86(5)\end{array}$ & $\left.\begin{array}{r}19 \cdot 1 \text { to } 36 \cdot 1 \\
4 \cdot 2 \text { to } 6 \cdot 4\end{array}\right\}$ & $\begin{array}{l}\chi^{2}=61.8 \\
p<0.001\end{array}$ & $\begin{array}{l}14(12) \\
99(6)\end{array}$ & $\left.\begin{array}{l}6 \cdot 8 \text { to } 19 \cdot 6 \\
4.9 \text { to } 7 \cdot 2\end{array}\right\}$ & $\begin{array}{l}\chi^{2}=5 \cdot 8 \\
p=0.02\end{array}$ \\
\hline $\begin{array}{l}\text { Lower gastrointestinal: } \\
\geqslant 80 \text { Years } \\
<80 \text { Years }\end{array}$ & $\begin{array}{l}196 \\
929\end{array}$ & $\begin{array}{r}41(21) \\
106(11)\end{array}$ & $\left.\begin{array}{r}15 \cdot 4 \text { to } 27 \cdot 3 \\
9 \cdot 4 \text { to } 13 \cdot 6\end{array}\right\}$ & $\begin{array}{l}\chi^{2}=9.4 \\
p=0.002\end{array}$ & $\begin{array}{r}26(13) \\
149(16)\end{array}$ & $\left.\begin{array}{r}8.8 \text { to } 18.9 \\
13.7 \text { to } 18.6\end{array}\right\}$ & $\begin{array}{l}\chi^{2}=0.70 \\
p=0.40\end{array}$ \\
\hline $\begin{array}{l}\text { Urinary: } \\
\geqslant 80 \text { Years } \\
<80 \text { Years }\end{array}$ & $\begin{array}{r}88 \\
657\end{array}$ & $\begin{array}{l}4(5) \\
9(1)\end{array}$ & $\left.\begin{array}{l}1.2 \text { to } 11.3 \\
0.6 \text { to } 2.6\end{array}\right\}$ & $\begin{array}{l}\chi^{2}=4 \cdot 3 \\
p=0.04\end{array}$ & $\begin{array}{r}6(7) \\
32(5)\end{array}$ & $\left.\begin{array}{l}2.5 \text { to } 14.3 \\
3.4 \text { to } 6.8\end{array}\right\}$ & $\begin{array}{l}\chi^{2}=0.54 \\
p=0.46\end{array}$ \\
\hline $\begin{array}{l}\text { Appendix: } \\
\geqslant 80 \text { Years } \\
<80 \text { Years }\end{array}$ & $\begin{array}{r}12 \\
1676\end{array}$ & $10(1)$ & $\left.\begin{array}{r}0 \text { to } 27.9 \\
0.3 \text { to } 1.1\end{array}\right\}$ & $F_{2}=1 \cdot 0^{\star}$ & $\begin{array}{c}2(17) \\
102(6)\end{array}$ & $\left.\begin{array}{l}1 \cdot 6 \text { to } 49 \cdot 1 \\
5 \cdot 0 \text { to } 7 \cdot 3\end{array}\right\}$ & $F_{2}=0.17^{\star}$ \\
\hline $\begin{array}{l}\text { Carcinomatosis: } \\
\geqslant 80 \text { Years } \\
<80 \text { Years }\end{array}$ & $\begin{array}{l}12 \\
94\end{array}$ & $\begin{array}{r}7(58) \\
26(28)\end{array}$ & $\left.\begin{array}{l}27 \cdot 2 \text { to } 85 \cdot 3 \\
18 \cdot 9 \text { to } 37 \cdot 9\end{array}\right\}$ & $\begin{array}{l}\chi^{2}=2.1 \\
p=0.15\end{array}$ & $\begin{array}{l}1(8) \\
3(3)\end{array}$ & $\begin{array}{r}\left.\begin{array}{r}0 \text { to } 39 \cdot 4 \\
0.6 \text { to } 9 \cdot 1\end{array}\right\}\end{array}$ & $F_{2}=0.38^{\star}$ \\
\hline $\begin{array}{l}\text { Other: } \\
\geqslant 80 \text { Years } \\
<80 \text { Years } \\
\end{array}$ & $\begin{array}{r}23 \\
284 \\
\end{array}$ & $\begin{array}{r}6(26) \\
44(15) \\
\end{array}$ & $\left.\begin{array}{l}10 \cdot 0 \text { to } 48 \cdot 7 \\
11 \cdot 5 \text { to } 20 \cdot 2\end{array}\right\}$ & $\begin{array}{l}\chi^{2}=1 \cdot 2 \\
p=0 \cdot 28\end{array}$ & $\begin{array}{r}2(9) \\
12(4) \\
\end{array}$ & $\left.\begin{array}{l}0.8 \text { to } 28 \cdot 5 \\
2.2 \text { to } 7 \cdot 3\end{array}\right\}$ & $F_{2}=0.27^{\star}$ \\
\hline $\begin{array}{l}\text { Total: } \\
\geqslant 80 \text { Years } \\
<80 \text { Years }\end{array}$ & $\begin{array}{r}446 \\
5301\end{array}$ & $\begin{array}{l}89(20) \\
281(5)\end{array}$ & $\left.\begin{array}{r}16.3 \text { to } 24.0 \\
4.7 \text { to } 5.9\end{array}\right\}$ & $\begin{array}{l}\chi^{2}=115.6 \\
p<0.001\end{array}$ & $\begin{array}{c}51(11) \\
397(7)\end{array}$ & $\left.\begin{array}{l}8 \cdot 6 \text { to } 14 \cdot 8 \\
6 \cdot 8 \text { to } 8 \cdot 2\end{array}\right\}$ & $\begin{array}{l}\chi^{2}=7.39 \\
p=0.006\end{array}$ \\
\hline
\end{tabular}

^Fisher's test of exact probability.

\section{Patients, methods, and results}

We analysed the records of a consecutive series of major abdominal operations performed on patients aged 80 and over between May 1971 and September 1986 and compared our findings with those in a contemporary series of all patients under the age of 80 undergoing similar operations. We recorded death within 30 days, either in hospital or at home; serious infective complications (serious wound infections and dehiscences, intraperitoneal sepsis, pneumonia, and bacteraemia); and other serious complications (cardiac failure or infarction; renal, hepatic, or cerebral failure; arterial thrombosis; intestinal obstruction; deep venous thrombosis; pulmonary embolism; and secondary haemorrhage requiring transfusion).

Altogether 446 operations were performed on 414 patients ( 241 women and 205 men) aged 80-101. Of these operations, 128 were elective, 141 emergency
1 Blake R, Lynn J. Emergency abdominal surgery in the aged. Brf Surg 1976;63:956-60. 2 Linn BS, Linn MW, Wallen N. Evaluation of results of surgical procedures in the elderly. Ann Surg 1982;195:90-6.

(Accepted 9 September 1987)

Scarborough Hospital, North Yorkshire YO12 6QL

A V POLLOCK, FRCS, FRCSED, honorary consultant surgeon

MARY EVANS, BA, research coordinator

Correspondence to: $\mathrm{Mr}$ Pollock. 